\title{
Perspective \\ Science for the Poor: How One Woman Challenged Researchers, Ranchers, and Loggers in Amazonia
}

\author{
$\underline{\text { Patricia Shanley }}^{1}$
}

\begin{abstract}
In the lower Tocantins region of Brazil, one Amazonian woman questioned why scientists publish principally for elite audiences. Her experience suggests that the impact may be enhanced by also sharing data with people who depend upon forest goods. Having defended her family homestead near the city of Cameta against loggers in the late 1980s, Glória Gaia became interested in strengthening the information base of other villagers so that they would not lose their forests for meager sums. She challenged scientists to defy norms such as extracting data without giving back to rural villagers and publishing primarily for the privileged. Working with researchers, she helped them to publish an illustrated manual of the ecology, economics, management, and cultural importance of key Amazonian forest species. With and without funds or a formal project, she traveled by foot and boat to remote villages to disseminate the book. Using data, stories, and song, she brought cautionary messages to villages about the impacts of logging on livelihoods. She also brought locally useful processing techniques regarding medicinal plants, fruit, and tree oils. Her holistic teachings challenged traditional forestry to include the management of fruits, fibers, and medicines. A new version of the book, requested by the government of Brazil, contains the contributions of 90 leading Brazilian and international scientists and local people. Glória Gaia's story raises the questions: Who is science for and how can science reach disenfranchised populations? Lessons for scientists and practitioners from Glória's story include: broadening the range of products from research to reach local people, complementing local ecological knowledge with scientific data, sharing precautionary data demonstrating trends, and involving women and marginalized people in the research and outreach process.
\end{abstract}

Key Words: Amazon; communication; forestry; impact; nontimberforest products (NTFPs); poverty; social change; women

\section{INTRODUCTION}

Despite large injections of donor money into the Brazilian Amazon and the vast production of scientific articles, deforestation rates are currently estimated at $25,000 \mathrm{~km}^{2}$ annually, demonstrating a steady increase since 1999 (Cleary 2006). Evidently, science is not enough. Or is it that the science that has been generated is not appropriately packaged and/or delivered into the hands of people who will use it? One contributing factor may be that relevant scientific findings are often not translated into a meaningful medium so that they can inform policies and practices in conservation and development (Saunders et al. 2006). In part, this may be because few scientists have the time, funds, training, or institutional mandate to take the necessary steps that lead to implementation and impact assessment phases.

The production of policy briefs and articles is routine; beyond this, there exist stiff institutional disincentives towards producing nonscientific publications. Scientists who do engage in sharing results beyond a scientific milieu frequently do so at a cost to their professional reputations (Pye-Smith 2003). Consequently, many rural communities in which research has been conducted are rarely on the receiving end of anything other than petty cash, false promises, and stale candy. The little that they do receive is not offered by scientists, but by politicians, loggers, ranchers, and agribusinesses. 
Glória Rodrigues Gaia is a forest farmer who fights for more than candy. Her story is one that raises questions about the scientific process, accountability to local stakeholders, and how to achieve impact. Glória's fury at extractive, elite science paved the way for an uneasy, but instructive collaboration. She helped our research team to turn science into practical outputs for common people. Bridging science and disenfranchised people takes perseverance and defiance; Glória has both.

\section{PROFILE OF A PEASANT CONSERVATIONIST}

Born in 1953 and bred in the woods near the town of Cameta, Brazil, Glória and her nine siblings were schooled in fishing, hunting, rubber tapping, and tree oil extraction. Her mother instilled in her a deep knowledge of medicinal oils and plants and passed on to Glória many forest-based remedies, including one fondly called chi chi do anjo (piss of the angel). Glória recalls, "Although we were financially poor, my parents gave us the rich cultural inheritance of our ancestors." From her mother and grandmother she inherited midwifery, and out of necessity began practicing at 17 years old. She vividly recollects, "Health care in isolated areas was extremely precarious. By 22 years old I had assisted 268 births."

She married at 23 years old, after which she had five children and moved into town. Surrounded by social and political causes, Glória fought for the rights of rural workers and women. During the late 1980s and early 1990s, Glória returned to her family's homestead to resist an advancing front of loggers. When most of her neighbors had little or no forest left, Glória continued to collect fruits, fibers, latex, game, and medicines from her woods (Fig. 1). She says that it helped her family like a bank account, "We did not have to buy all of our foods and remedies; the woods have also been our source of sustenance."

Cash poor and hungry, villagers like Glória are often in a poor negotiating position with loggers, ranchers, and agribusinesses. After saving her own tract of forest, Glória became committed to helping other villagers negotiate better deals for their forests. In 1993, she heard of research on a logging frontier along the Capim River where our small team of scientists was helping villagers to answer the question: Which is more valuable, our trees sold as timber or the game, fibers, and fruits that we collect from our forest?

Answering the community's question was not simple. Through a local, national, and international partnership, i.e., the Rural Workers Union of Paragominas, Brazil's National Agricultural Research Center, Embrapa, and The Woods Hole Research Center, respectively, we began a longterm engagement with the communities that continues presently with the Center for International Forestry Research. Low densities of economic species, wildly inconsistent fruit production, declining populations of game, and rising intensities of logging and fire contributed to making the research site ever-changing and complex. Whilst bemoaning dwindling resources, village leaders continued to sign logging contracts.

Glória's interest in the work helped our research team to solve an ethical dilemma. At a local level, how could we conduct ecological research that would not provide any immediate solutions to stem the loss of fruit, game, and medicines? At a landscape level, how could we ensure that the rapid destruction we witnessed would serve as a warning, so that it might be avoided by other communities?

In 1994, in response to Glória's request to share our research findings, we created a traveling show. We took the workshop materials, posters, stories, and data, which we had used to convey the results to the Capim villages, on the road. A hunter from the Capim, a fellow researcher, and I strapped hammocks and posters to our backs and began our journey with Glória by boat, muddy logging road, and foot to a distant village in the lower Tocantins region that was beset by pressure from loggers.

\section{A TRAVELING WORKSHOP TO EMPOWER VILLAGERS}

Glória disliked scientists, particularly foreigners. She likened scientists to ranchers and loggers: pompous, wealthy, and pursuing an extractive activity and leaving little behind. During the initial trip together, we did not escape Glória's wrath. She tolerated us because we had data that the villagers needed as the loggers and ranchers arrived.

Which data were the most relevant to the villagers? To many, game was the most important forest product and the preferred source of protein. Hunters 
Fig. 1. Glória, at the far right, conducts medicinal plant workshops to illustrate how some common illnesses can be treated effectively using local plants. Photo: Joel Sartore.

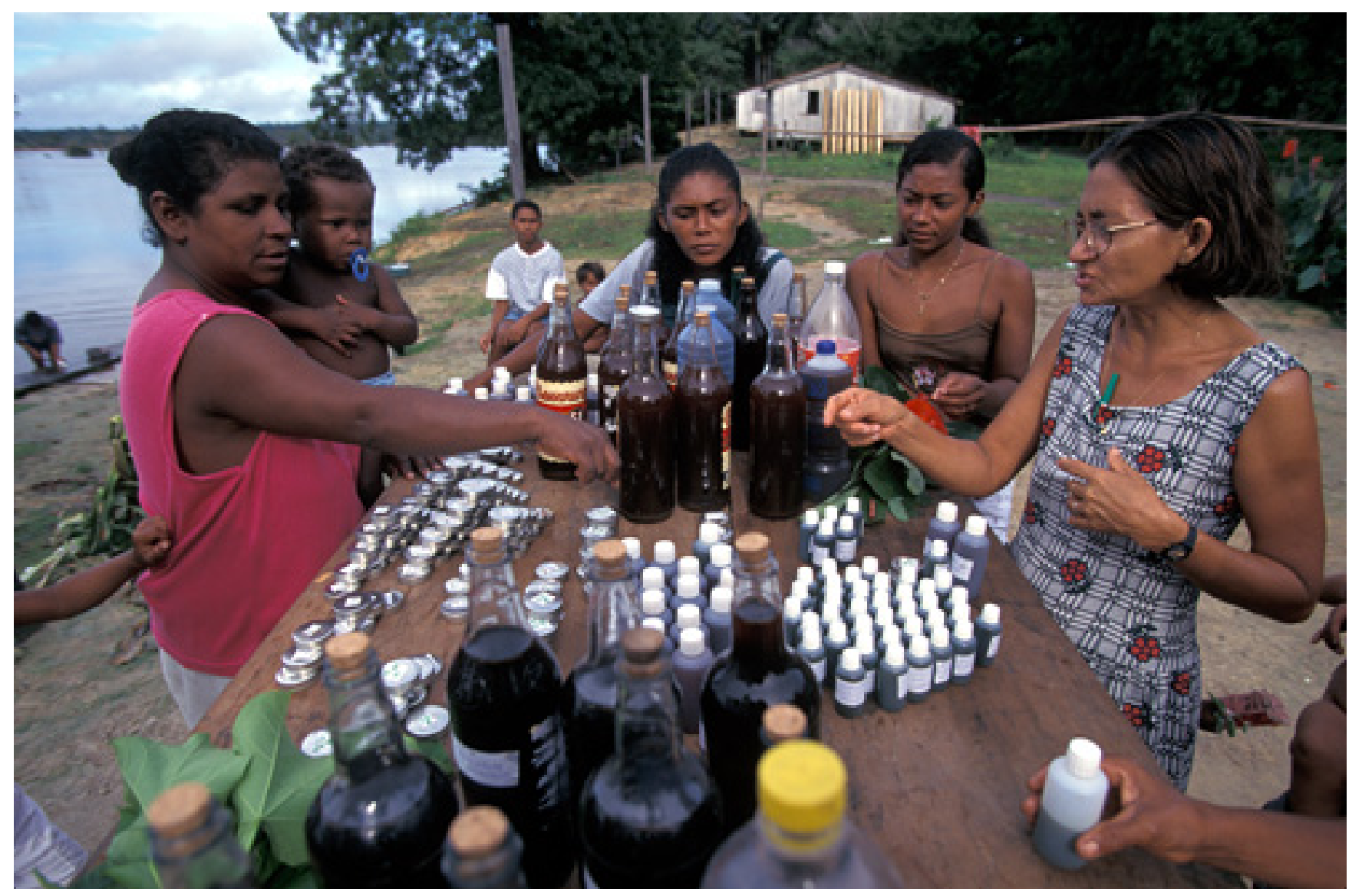

were fascinated to see rankings of which tree species attracted the most wildlife; they marveled at how seven hunters in one village captured $232 \mathrm{~kg}$ of game under a few piquiá, Caryocar villosum, trees and at how much that would cost to purchase in town (Shanley et al. 2005; Figs. 2 and 3).

Villagers were also interested in the quantities of forest fruit produced annually within 1 ha of land and the prices of fruit as compared to timber in the marketplace (Fig. 4). A bacuri, Platonia insignis, tree, for example, produces on average 300 fruits per year, with potential revenues of the equivalent of US \$30, as compared to approximately US \$1 per tree for its timber (Fig. 5). Longitudinal data offered a sobering tale illustrating the rapid and dramatic consequences of repeated logging to livelihoods (Fig. 6).
The first traveling workshop to the lower Tocantins region was an eye-opener. Through Glória's interest, we learned that the research we had conducted for years along the Capim River resonated in a new setting. As in the Capim, the invisible income from fruit, game, and fibers was substantial, but the cash offered by loggers seduced village leaders to sell timber repeatedly. Role playing catalyzed lively debates between "loggers," "fruit vendors," and "villagers." Glória broke into a speech against unscrupulous foreign investment in timber. As we prepared to leave, villagers thanked us warmly and continued deliberations on how to strengthen customary regulations on forest use.

We began the hike out before sunset. In the dimming light we passed itinerant saw mills: domestic, nimble operations with transportable equipment, 
Fig. 2. Quantities of game animals captured beneath different tree species during $1 \mathrm{yr}$ in one Capim River community. Source: Cymerys in Shanley and Medina (2005).

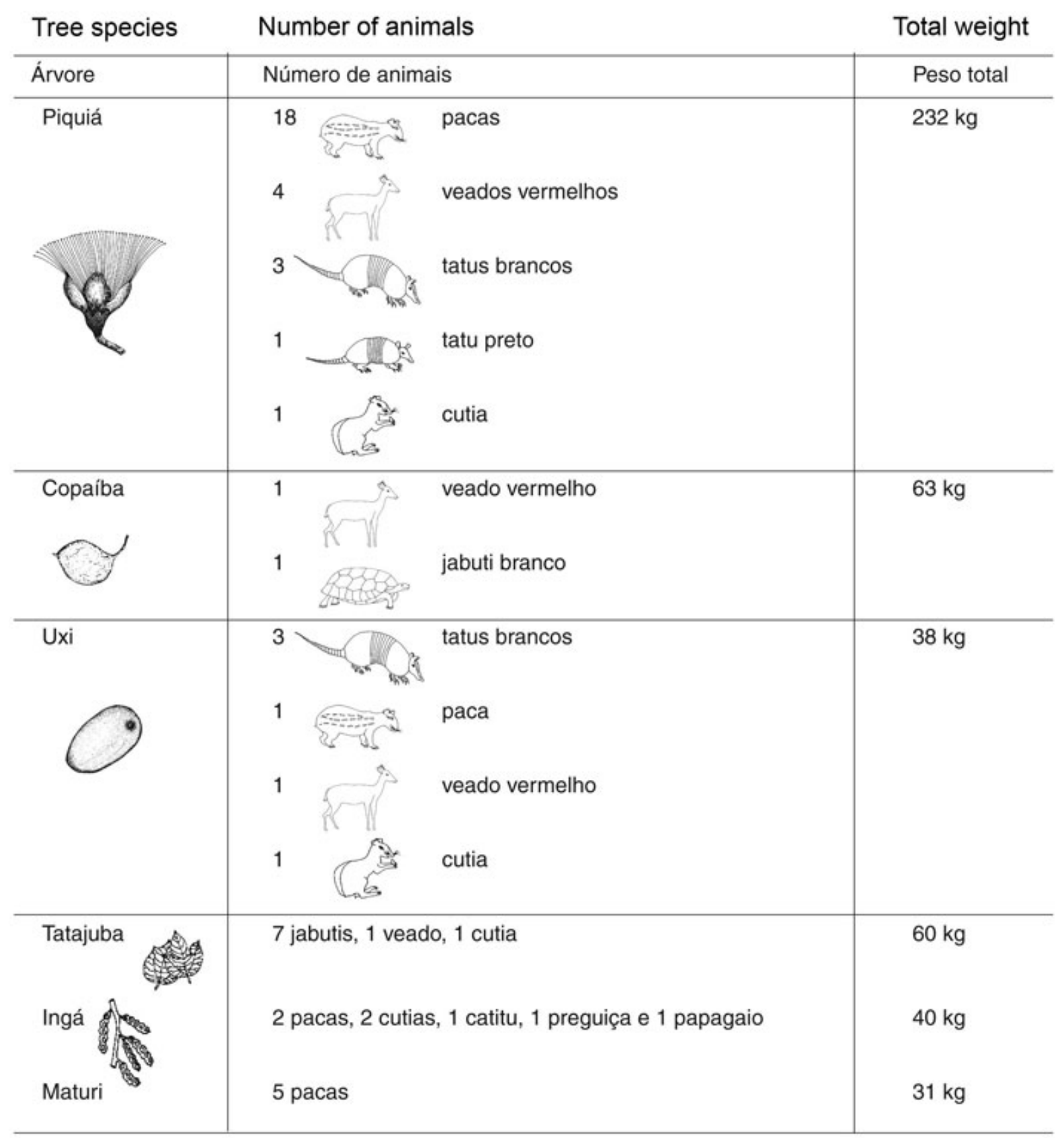


Fig. 3. The cost of game meat captured freely in the forest if purchased in the local market. Source: Cymerys in Shanley and Medina (2005).

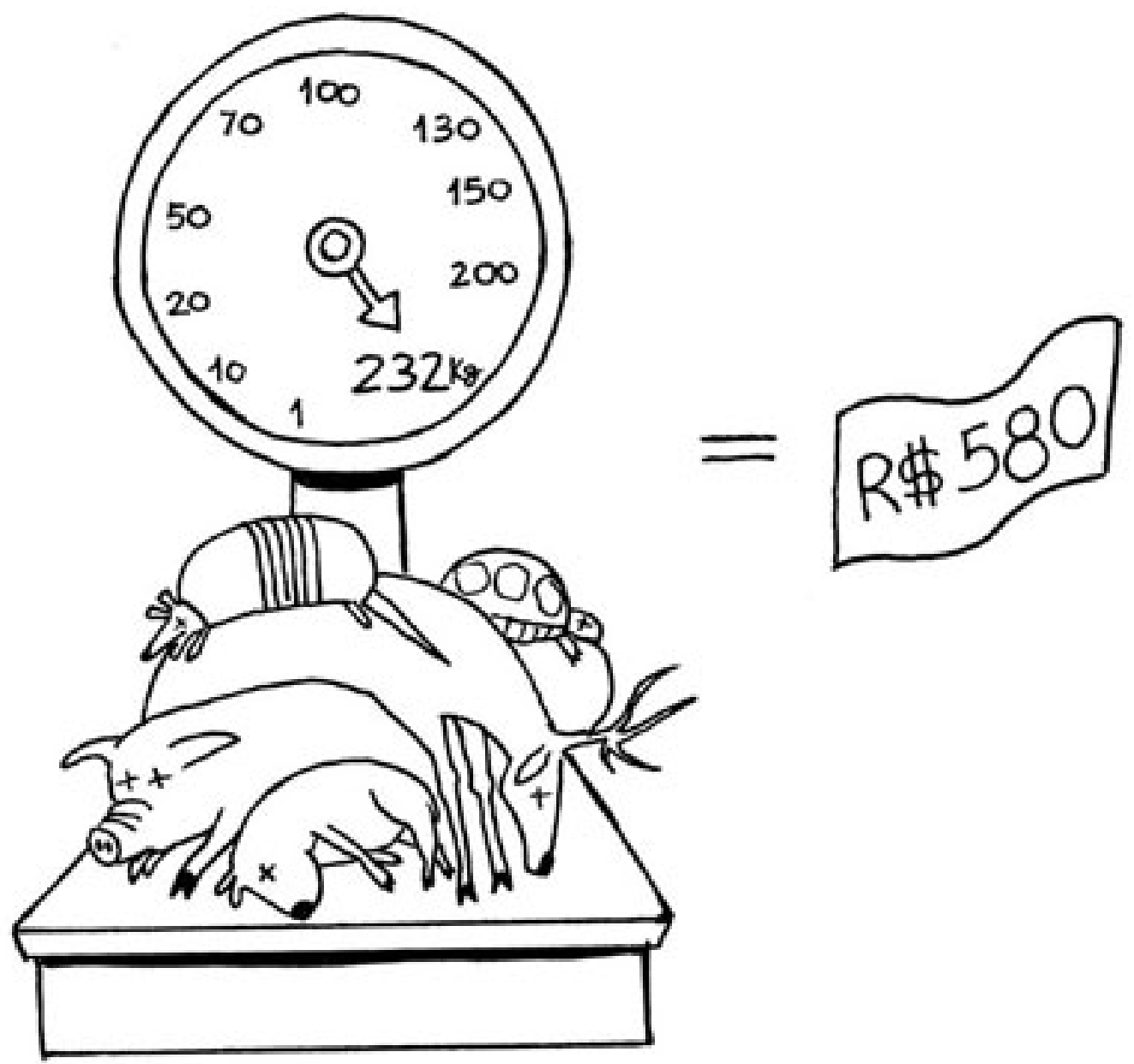


Fig. 4. Calculation of the value of fruit from 1 ha of forest. Source: Shanley and Medina (2005).

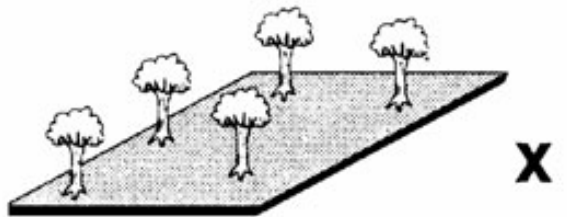

5 trees per hectare

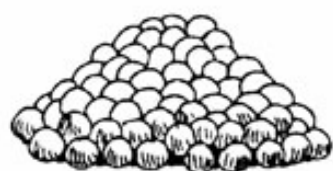

400 fruits per tree

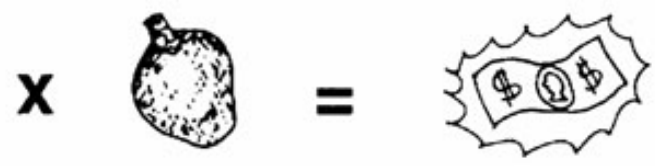

R\$ 0.25 / fruit

$\mathbf{R} \$ \mathbf{5 0 0}$ efficient at reaching remote areas. Sawmills, big and small, had beaten us here and would beat us everywhere. The forest would continue to fall and sometimes, it would be due to a villager's lack of knowledge of its value. Defeated and worn out, we forded a stream, holding our back packs and posters above our heads until we made it to the other side. As we hiked on in the semi-darkness, an idea began to form among us: the need for a portable tool to empower communities, traveling workshops on paper, a book for the semi-literate.

On the return boat ride, we drew pictures. In rural areas, the lack of formal education signifies that many villagers are illiterate; information to weigh trade-offs would need to be presented in an illustrated format. But how could we illustrate species phenology, production, yield, economics, and management? On scrap paper, we experimented with pictorial representations of complex information. These initial sketches became the templates for the "traveling workshop" book (Fig. 7).

\section{CONNECTING SCIENCE AND CULTURE}

The science had to be rigorous. Farmers and hunters could not be fooled; they survived off of the species that we merely studied. However, Glória also taught us that numbers would not be enough. Numbers could offer a technical grounding, but they would not inspire respectful negotiations, equity, or conservation. In rural villages, forests do not merely signify ecology and economics, but also song, story, culture, and healing.
Thus, the book needed to be written not only by Amazonian authorities, but by swidden farmers, hunters, and midwives, like Glória. We added logging tales, cultural jokes, forest legends, soap and cake recipes, oil processing information, and tips for planting fruit trees. Cartoons illustrated how formerly belittled Amazonian fruits had created a sales frenzy in fitness centers of distant, cosmopolitan São Paulo (Fig. 8). Stories revealed that not only rural Amazonians, but even American forestry professors, get ripped off by loggers (Fig. 9).

Glória also helped us to weave songs from workshops into the book. In one upbeat tune a man sells his forest to a land baron, he moves to the city, his children become hungry, his wife fights with him, he cannot find even menial labor, and his family sinks into a grinding, irreversible cycle of urban poverty. In a slower beat to a Brazilian dance rhythm, a songwriter asks, "Where have all our fish gone? Where are all our trees? They have gone away with everything, only hunger remains" (Appendix $1)$.

\section{Science for the semi-literate: the fruit book}

With cataract-ridden eyes, no health plan, and a pair of broken glasses, Glória struggled to read. Her difficulty mirrored that of many other rural people and helped us to choose a large font, insert a multitude of pictures per page, and stick to a simple format. In 1998, on the day the book was first printed in Belém, Glória stood by at the publishing house, grabbed a copy, and ran it over to the Mayor's office. By this time, the book had attracted a new audience; 
Fig. 5. Gloria and a hunter compare the value of fruit and timber. Photo: Joel Sartore.

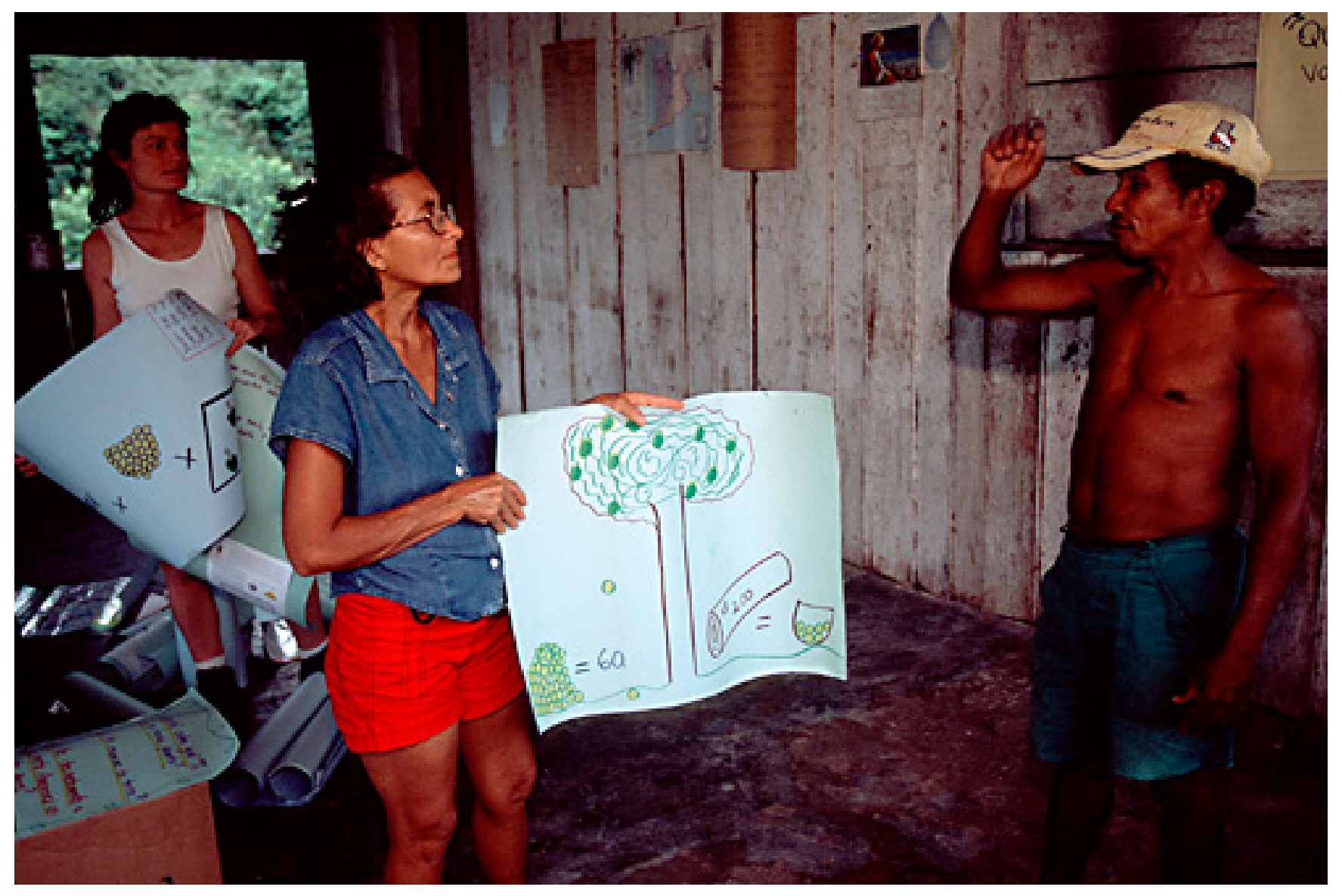

teachers, taxi drivers, urban housewives, and loggers had begun seeking it.

Throughout the 7 yr after the first book, Frutiferas da mata na vida Amazônica (Fruit trees of the forest in the lives of Amazonians; Shanley et al. 1998) was printed, Glória distributed copies to villagers in need of information. She traveled, often without funds or a formal project, by logging road, canoe, and foot to conflict-ridden regions to conduct workshops on forest value (Appendix 2). Armed with data about the ecology, markets, and management of a dozen Amazonian tree and palm species, she sought to inform discussions and catalyze change.

Glória used the book as a tool to empower rural villagers with rigorous science and give them a voice. Toward this mission, Gloria worked in villages side-by-side with like-minded activists such as Sister Dorothy Stang, who devoted decades of her life in support of peasant farmers. Like other colleagues of Glória's, Sr. Dorothy was killed in 2005 by a hired gunman as she walked calmly in prayer to a village meeting.

\section{EMPOWERING WOMEN THROUGH FOREST PRODUCTS}

One day during field work, the most macho of our researchers, Jurandir, turned to us and proclaimed, "If we do not work with women, the forest will fall." In village after village, we discovered that women and nontimber forest products have much in common (Appendix 3): both are critical, but marginalized. Left out of land use decisions, women 
Fig. 6. Timber extraction can be compatible with the use of forest products such as fruits, depending on the frequency and intensity of extraction. Source: Shanley and Medina (2005).

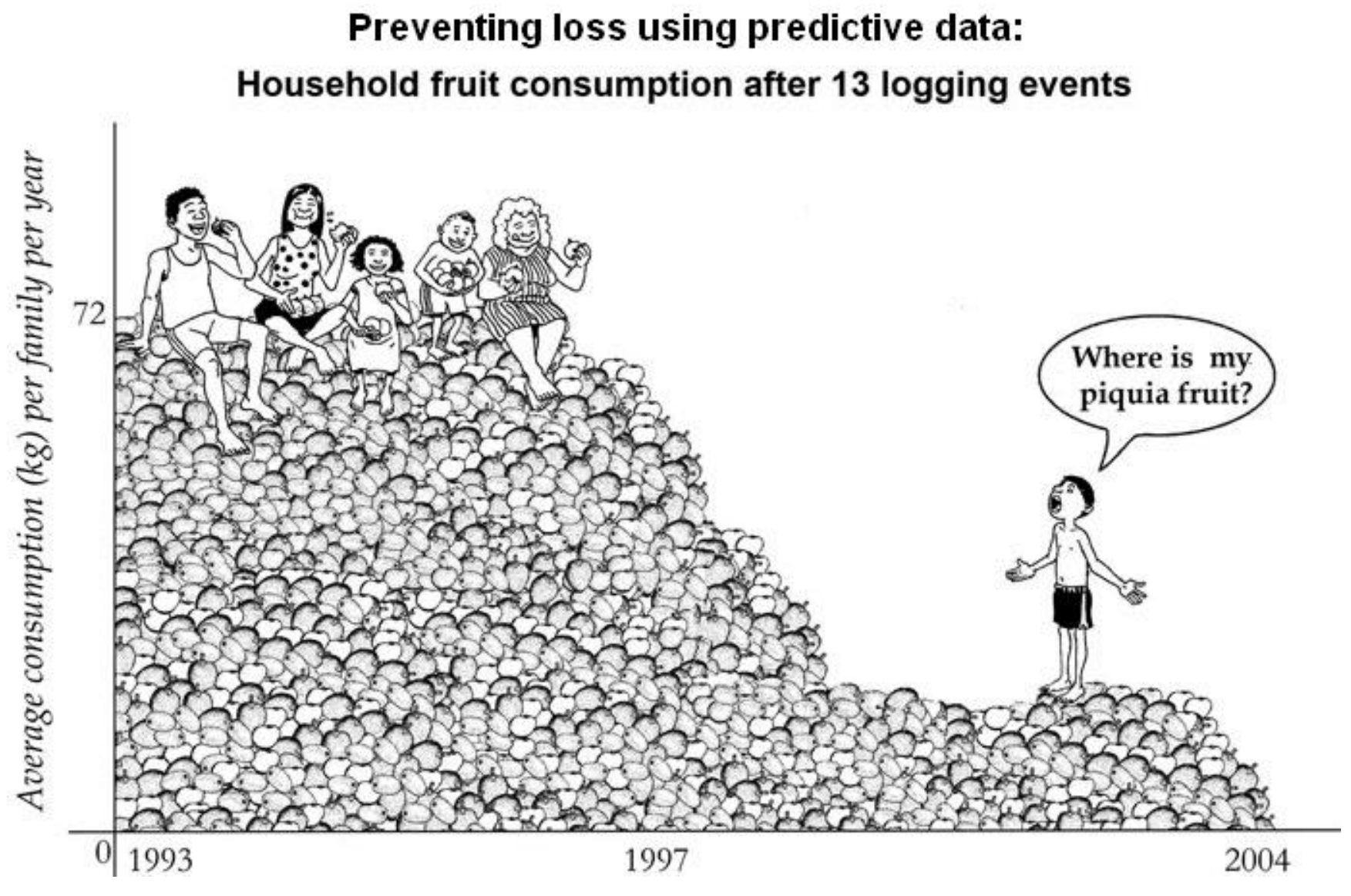

use forests to sustain their families, but have little voice in managing these critical resources.

Glória's mere presence in villages stirred change. After Glória's visit, the matriarch of one of the Capim River communities, Dona Ana proclaimed, "If I had been here to stop it, this last timber sale would never have occurred." Women began protesting logging, questioning their husbands for downing profits in drink. After learning that the potential value of the forest fruits outstripped timber by a factor of between 15 and 30, some women took to the woods in pursuit of fruits. One woman's family resisted the loggers, turning their forest into a reserve (Fig. 10). Other women and men improved their negotiations with loggers, conserving valuable fruit and medicinal oil trees (Fig. 11). During community meetings, men began to join their wives in singing a catchy tune that Glória taught (Fig. 12), "To change society, we need women; without women we fight with only half the force."

\section{FIGHTING FOR SYSTEMIC CHANGE}

\section{Technical forestry: training a new generation}

Not content to work only at the local level, Glória has also fought for systemic change by challenging traditional forestry curricula, which concentrates principally on timber production. In December 2000 , at the International Union of Forestry Research Organizations Symposium on Integrated Management of Tropical Rainforests held in Belém, 
Fig. 7. Illustrations convey the phenology, density, and fruit production of jatoba, Hymenaea courbaril. Source: Shanley and Medina (2005).

\section{ECOLOGIA}

\section{Época de flor e fruto}

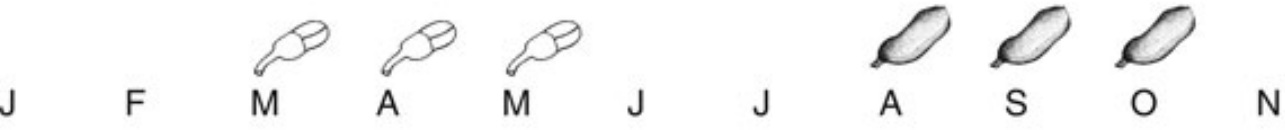

O jatobazeiro floresce durante a estação seca e frutifica depois de 3 a 4 meses. No Pará, a árvore de jatobá floresce entre março e maio e frutifica entre agosto e outubro; na Amazônia Central, frutifica de fevereiro até setembro;' no Acre, de maio a setembro. ${ }^{2}$

\section{Densidade}

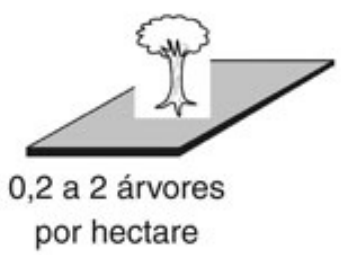

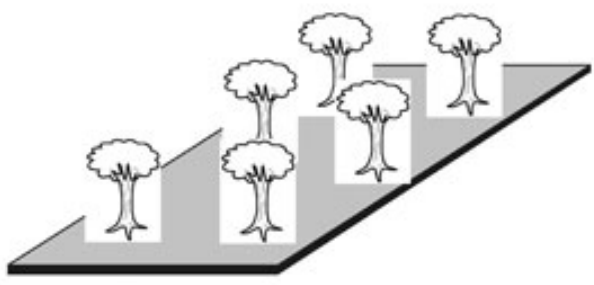

1 a 10 árvores por alqueire

É uma espécie rara (menos de 1 árvore por ha) com distribuição irregular. A abundância de jatobá está diminuindo por causa da extração de madeira.

\section{Produção}

A produção de jatobá varia muito. Uma árvore normalmente não produz frutos todos os anos. Muitas "descansam" em um ano e produzem no outro. Enquanto algumas árvores produzem pouco, outras chegam a produzir até 2.000 frutos.

A casca de jatobá possui aproximadamente $40 \%$ de água em sua composição. Cada 100 quilos de casca úmida produz 60 quilos de matéria seca. Uma árvore também pode produzir até 15 quilos de resina.

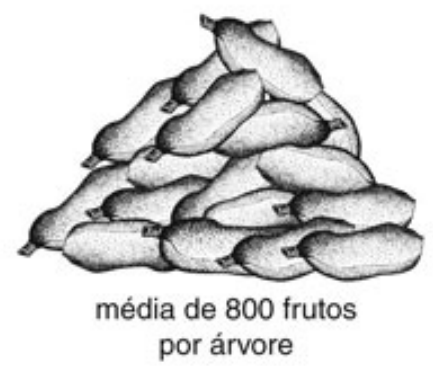

\section{VALOR ECONÔMICO}

Em 2004, no Ver-o-Peso, em Belém, os frutos de jatobá foram vendidos a $\mathrm{R} \$ 0,10$ a unidade; o litro da seiva a R\$ 4,50; uma casca a R\$ 1 e o quilo da casca a R\$ 4. Em 2002, em Rio Branco, na Casa de Ervas, Toca do Coelho e Mercado Municipal, a casca foi vendida em saquinhos de 100 gramas por R\$2. A madeira de jatobá é uma das mais aceitas no exterior. Nas serrarias de Tomé-Açu, o metro cúbico cerrado está valendo $\mathrm{R} \$ 380$. 
Fig. 8. Sales of Amazonian fruit juice have skyrocketed in fitness centers in São Paulo. Source: Shanley and Medina (2005).

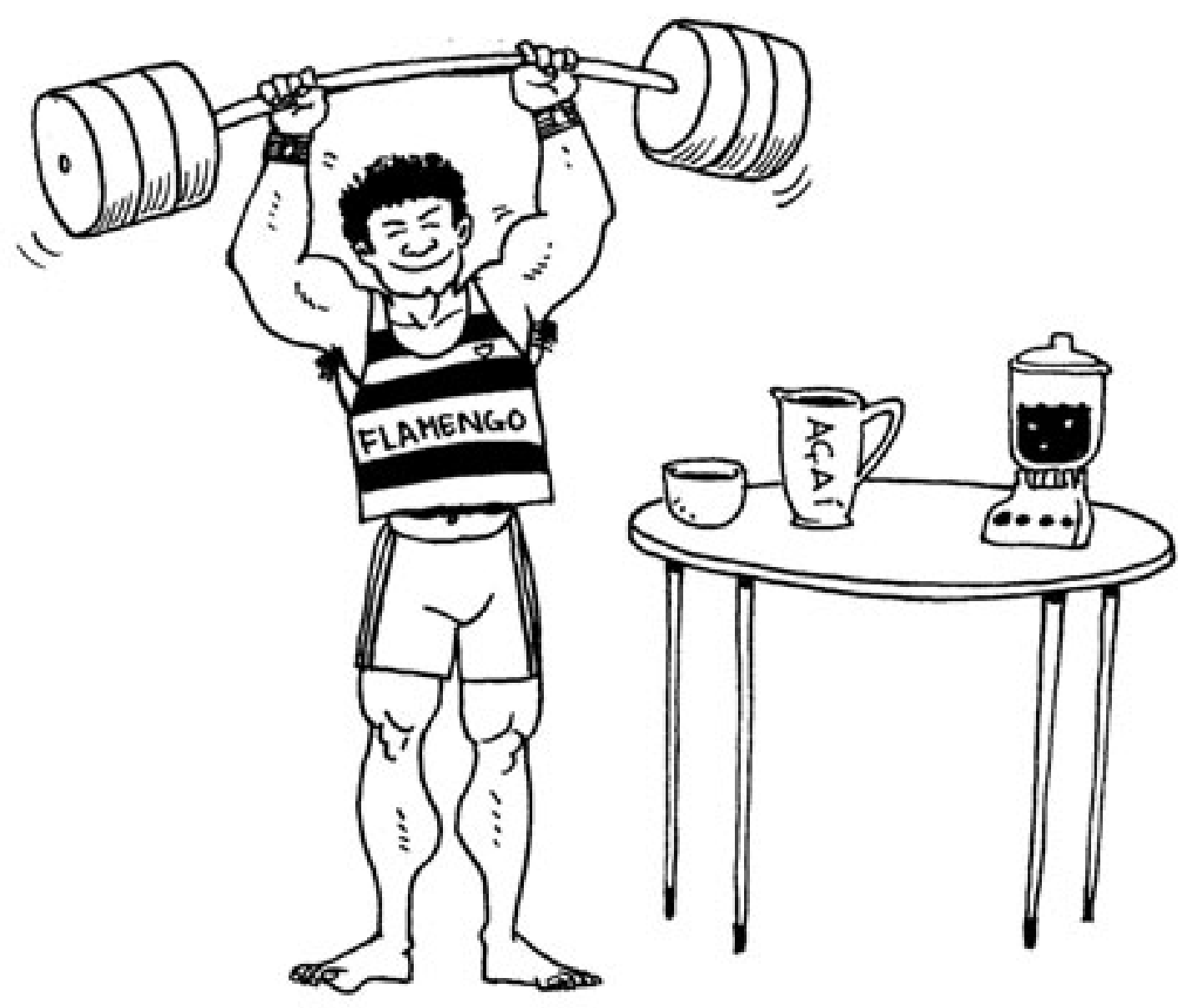


Fig. 9. A well-informed American professor of forestry also loses out to a logger. Source: Shanley and Medina (2005).

\section{Being fooled by loggers happens the world over}

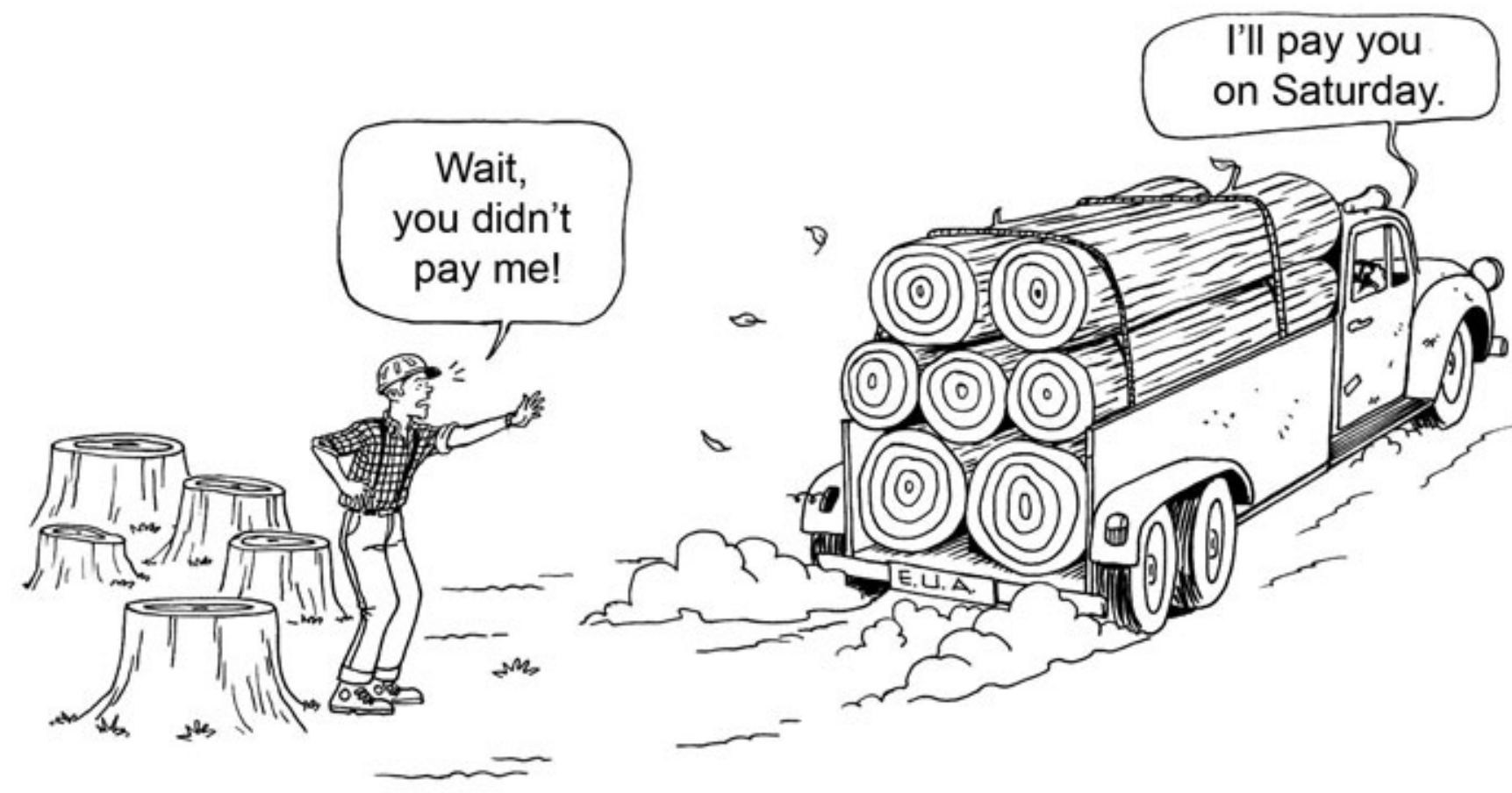

Glória presented the Center for International Forestry Research's Mulheres da Mata (Women of the Forest) project on nontimber forest products, unabashedly offering a holistic perspective on multiple-use forest management. She was also delighted to be invited to present the team's work at Natura in São Paulo, one of Brazil's leading cosmetic companies that works with natural products.

At meetings filled with foresters and timber industries, Glória received rousing applause from community members, especially the elderly, women, and children, to whom her message about diverse forest products struck a nerve. Impressed, a teacher at the Agro-Technical School of Manaus invited her to teach on forest fruits and medicines.
Her workshops became so popular that a nontimber forest product component is now part of their standard curriculum, a development that some consider revolutionary for forestry education in the region.

\section{Education: weaving in Amazonian culture}

Not privy to the coffee table books published in the north, rural Amazonians often have less information than New Yorkers on the death toll being sounded for the woods that they live in. School books used in Amazonian classrooms are written in São Paulo. Responding to demand from rural and urban teachers, Glória and colleagues Gabriel Medina and Flavio Contente from the Mulheres da Mata team 
Fig. 10. Maria Brito and her children collect medicinal bark in their family forest reserve. Photo: Patricia Shanley.

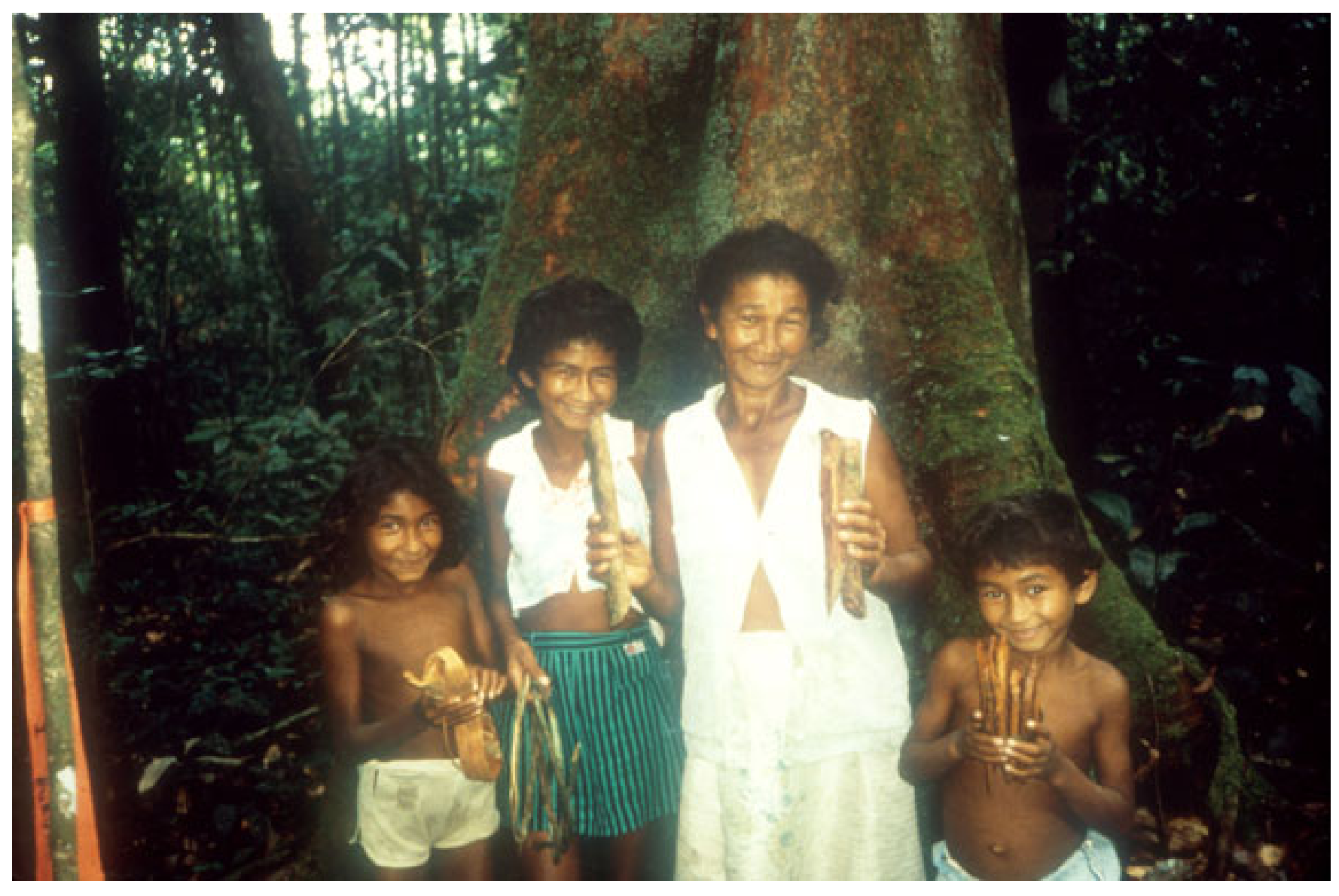

began teacher training workshops. The geographic reach of the team expanded when a pioneering university professor, Dr. Salomão Hage, realized the book's potential for a basin-wide governmental program, Pronera, supporting adult rural literacy training.

\section{Governmental support: winds of change}

In 2000, Glória and I were invited to travel west to the Brazilian state of Acre. There, Carlos Vicente and Aldaberto Veríssimo, current advisors to Brazil's Minister of the Environment, requested an expanded version of the Frutíferas book to include species from Acre and across the basin (Shanley and Medina 2005). As a result of that meeting, Glória's backpack is now heavier as she makes her way to villages. The book expanded from 100 to 300 pages. The first version included contributions by only a handful of scientists and forest people; the new book includes the research of 90 leading Brazilian and international scientists covering 21 species. Esteemed ecologists, economists, and anthropologists, as well as high-level policy makers broke with tradition, wrote simply, and embraced the voices of rural people. They published with the belief that cartoons and stories would not diminish, but rather enhance the impact of their findings by bringing them to a broad audience. 
Fig. 11. Families negotiate to conserve valuable fruit and medicinal oil species.

\section{Science strengthens rural capacities}

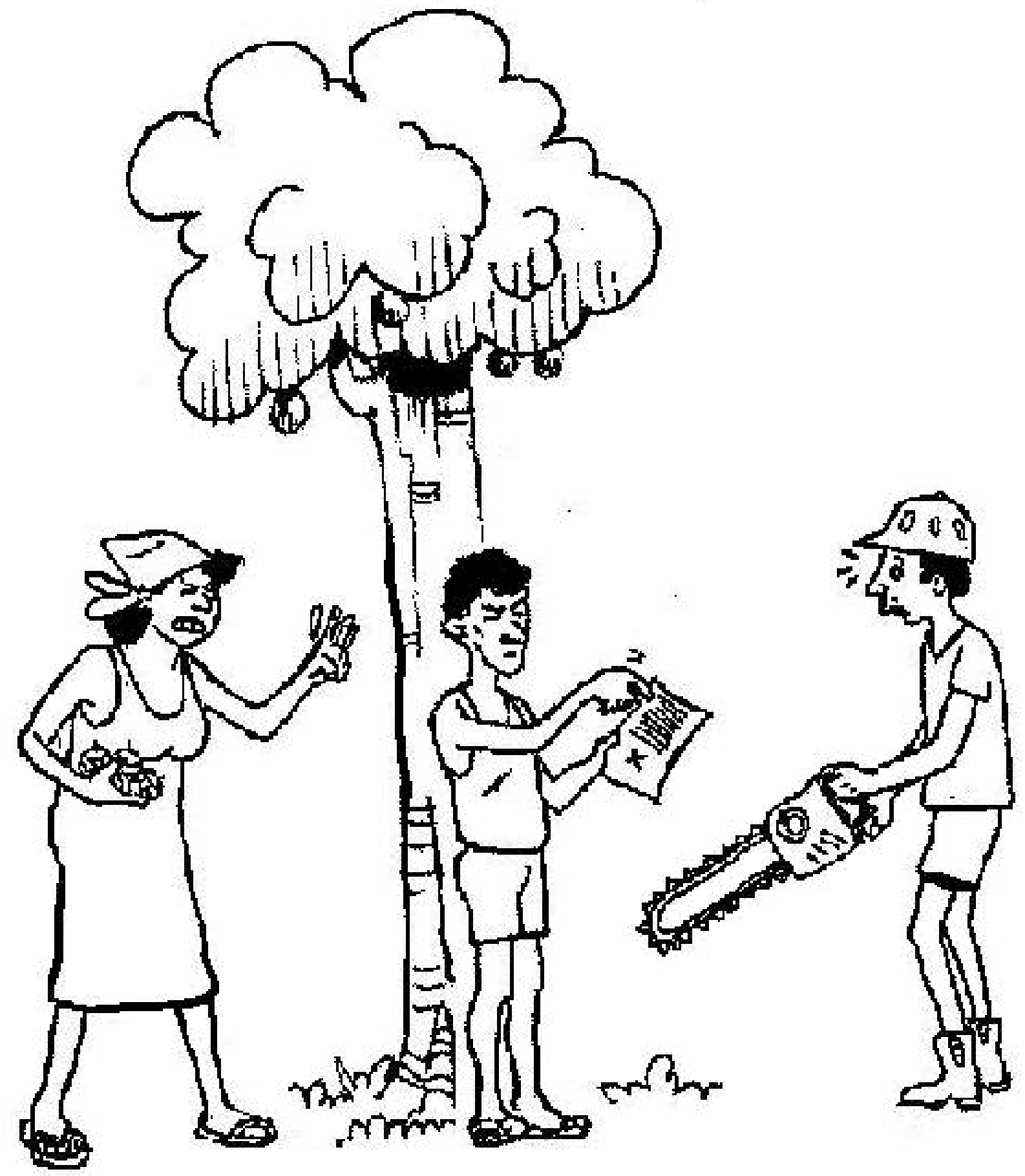


Fig. 12. Brazilian researcher Jurandir Galvão sings a women's rights song at a demonstration for social and environmental justice. Photo: Patricia Shanley.

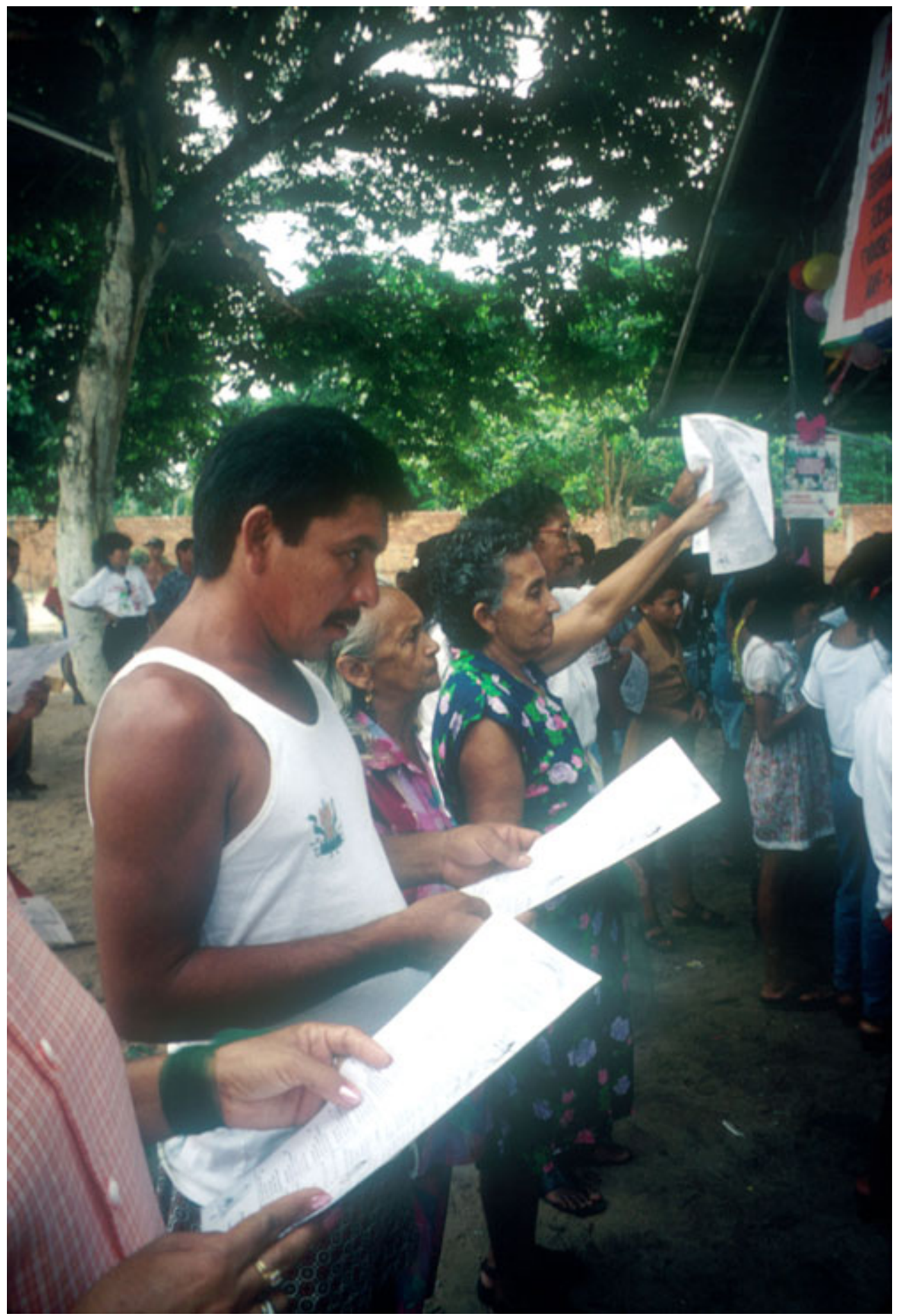


Fig. 13. Brazilian Minister of the Environment Marina Silva celebrates the launching of the Frutiferas book. Photo: Jeferson Rudi.

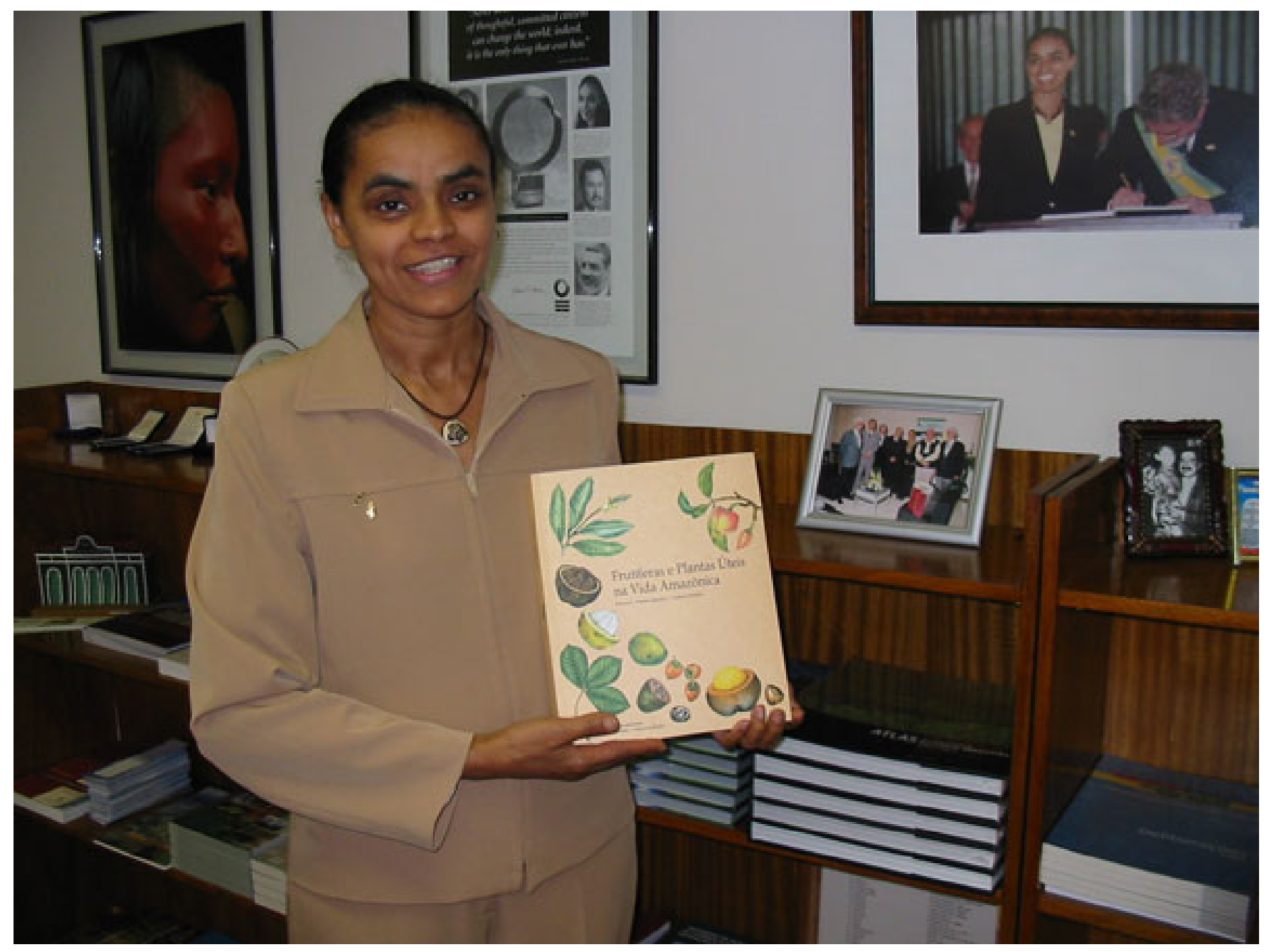

\section{VISON FOR THE FUTURE}

Today, with the creation of extractive reserves in Amazonia and the newly created Brazilian Forest Service, the type of work that Glória and collaborating scientists have conducted on multipleuse forest management may be more important than ever. The Brazilian Institute of Tropical Forestry has requested that the Mulheres da Mata team help them to integrate a nontimber forest component to their nationally recognized forestry training workshops. The National Council of Rubber Tappers and an educational program, Casas
Familiares Rurais, are strengthening rural households by holding workshops that use the Frutiferas book. Tasso Rezende, director of the newly created Brazilian Forest Service, is breaking new ground by initiating community forestry training for timber and nontimber forest products across the Brazilian Amazon.

However, seeing is believing. In 2004, film-maker Trilby MacDonald documented the work of Glória and other women activists in a documentary entitled, Mulheres da mata (Daughters of the canopy; MacDonald 2004). The following year, the 
Fig. 14. Farmers successfully manage the fruit tree Endopleura uchi, whereas scientific literature states that it is not viable to plant. Source: Shanley and Medina (2005).

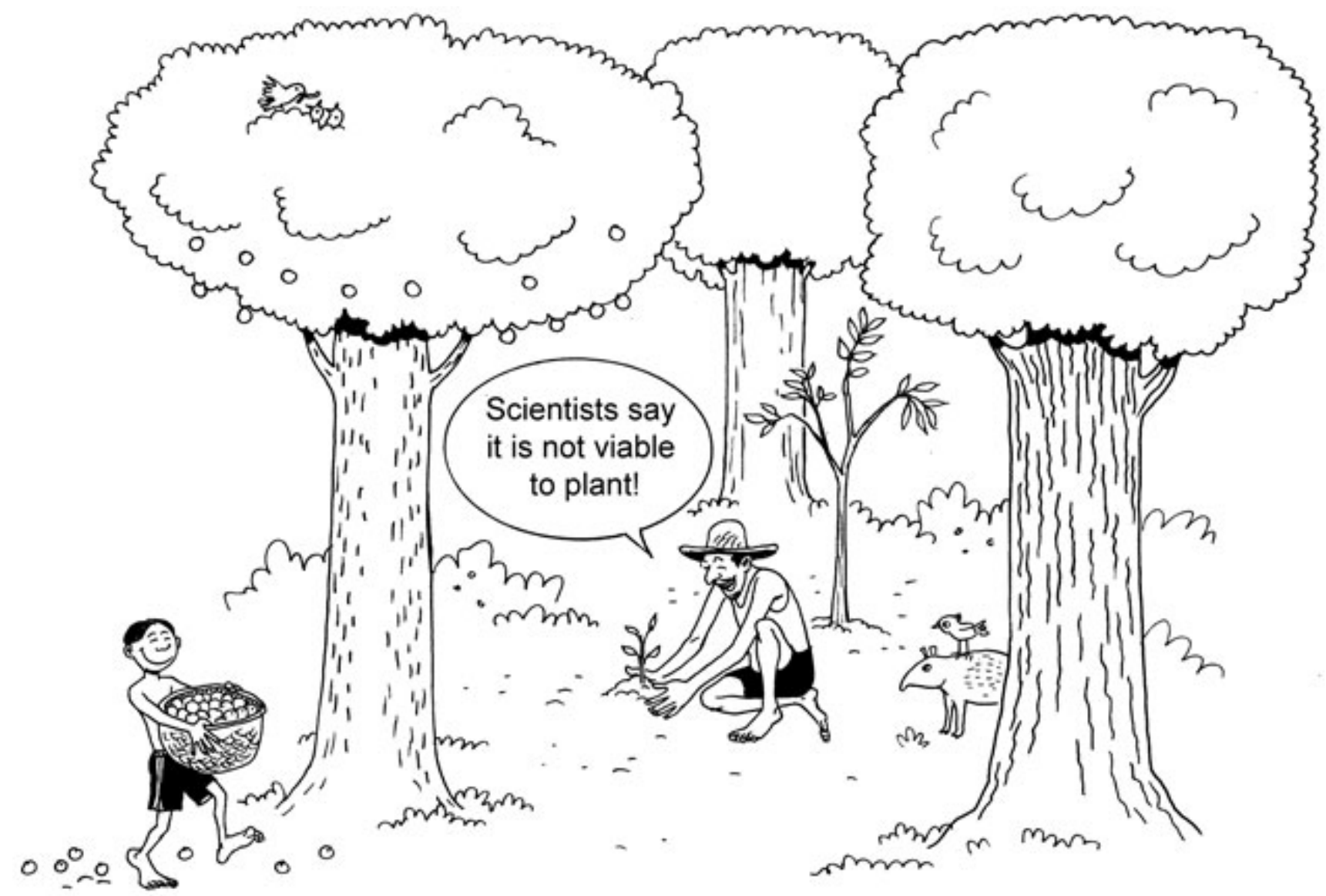


Fig. 15. Exchanges among rural communities can provide critical information for more informed land use decision making. Source: Shanley and Medina (2005).
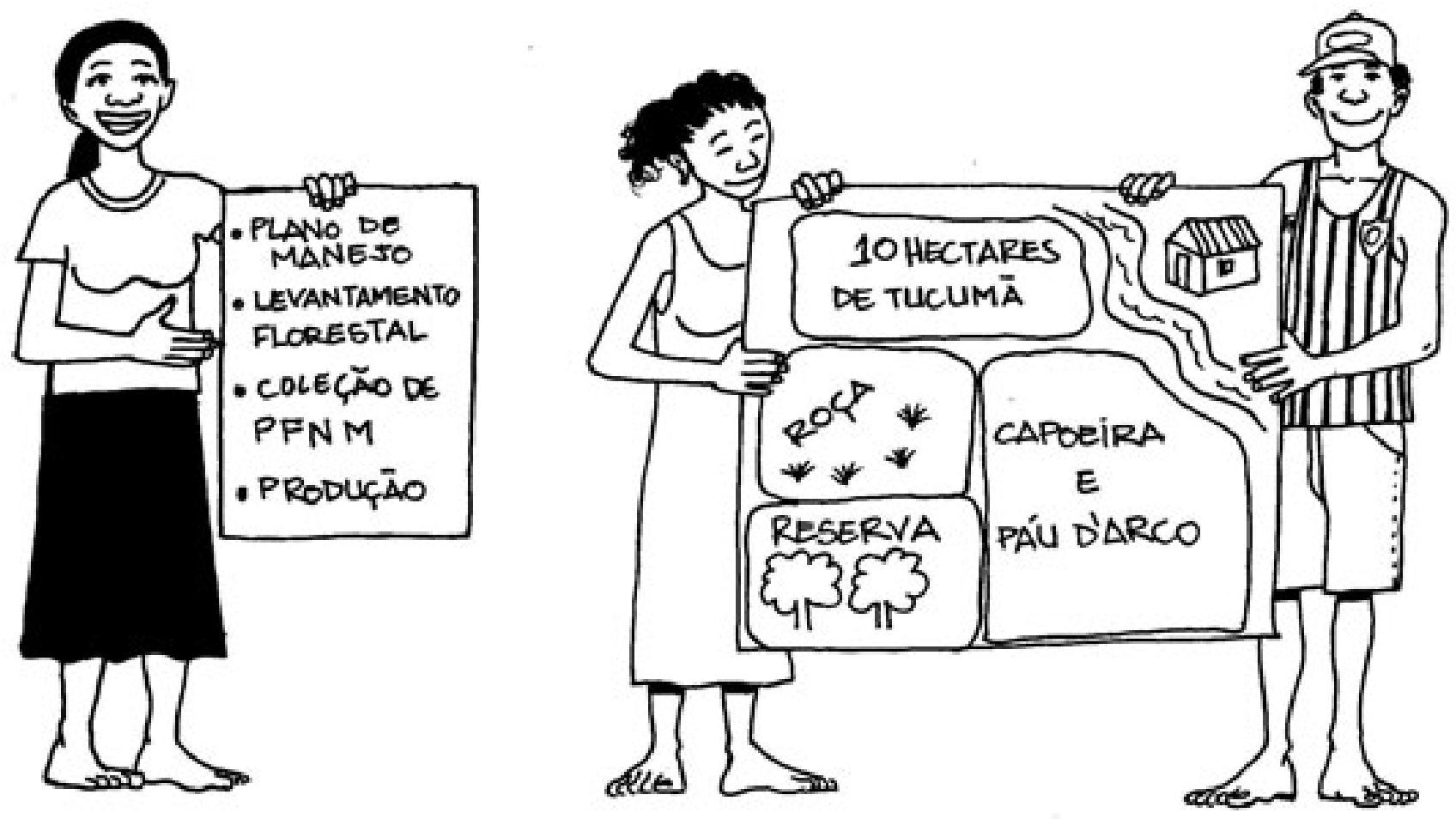
new version of Frutíferas, which Glória helped to catalyze, won an international award for outstanding communications from the World Bank and the Consultative Group on International Agricultural Research. In the preface to the book, Marina Silva (Fig. 13), Brazil's Minister of the Environment and a long-time supporter of the work, wrote, "With rigorous and simple language, this extraordinary book brings information to the people that is fundamental to realize the dream of a sustainable Amazonia."

\section{The gap: falling through the cracks}

Unfortunately, support for on-the-ground outreach work such as that conducted by Glória is wanting. Scientists obtain funds for research, not extension. Forestry extension agencies continue to primarily teach timber extraction, not multiple-use management of fruits, fibers, resins, and oils. Development organizations focus on people, not forests. Research and extension agencies generally hire formally schooled staff, not forest farmers and women from rural areas.

If extractive reserves are to become more than paper parks, however, their inhabitants need reliable information. If small land holders and indigenous populations who manage one-third of the Brazilian Amazon are to manage the forest for timber, as well as fruits, wildlife, fibers, and resins, they will need information and processes with which to critically analyze their choices. From whom, how, and where can remote forest villagers obtain reliable information? Against predatory loggers, a macho Latino society, and elite scientists, Glória struggles on to reach such forest villagers. What are some of the lessons that Glória and her story leave with us?

Some possibilities for action:

\section{Share precautionary data demonstrating} trends. Living in isolated scenarios, marginalized people are often unaware of the rapidity with which land use change can occur and the specific consequences for their own lives. Rural residents can make better informed decisions when they have access to information about trends and negotiation processes prior to negotiating with loggers, ranchers, and agribusinesses. Modeling, satellite imagery, community mapping, negotiation support, and future scenarios are among the tools that can help villagers in this process.

2. Select research questions with relevance at multiple scales. Research questions conceived in city offices may not generate results with relevance to local, national, or global stakeholders. Jointly conceiving of research questions with a range of stakeholders can ensure that the questions need to be asked and that the results will have an audience. Bridging scales can be accomplished by addressing questions that resonate at multiple levels.

3. Encourage accountability beyond the project cycle. Few researchers return to research sites for follow-up work and few donors support long-term funding cycles. However, relationships with local and national stakeholders beyond and/or between funding cycles can generate needed longitudinal data, improve researchercommunity-government relations, promote a more equitable research process, and raise the potential for impact.

4. Bridge policy makers and local people. Scientists have the privilege of access to legislative bodies that can either improve or impede access to and benefits of natural resources for marginalized populations. Local people are critical actors in the conservation of biodiversity (Agrawal and Ostrom 2006). Helping to bring the voices of local people to policy makers is a key role for scientific organizations and their civil society partners.

5. Complement local ecological knowledge with scientific findings. Local knowledge can offer an irreplaceable foundation for research and development (Fig. 14). However, local ecological knowledge is often insufficient, particularly in dynamic land-use scenarios. Scientists are well placed to assess whether and how local knowledge can best be complemented with needed socioeconomic, environmental, and policy-related findings.

6. Communicate effectively by promoting diverse research products. Peer-reviewed publications are critical to ensure rigor in science. Building upon journal articles and 
expanding the range of research products can reach a broader audience and catalyze wider impact. Donors, universities, and training and research institutes can remove disincentives and/or offer incentives to scientists who work with partners to share their results with broader audiences.

7. Create space for a diversity of voices, including those of women. For pragmatic reasons, conservation projects need to pay serious attention to women. Research has shown that involving multiple stakeholders (men and women) in the early stages of the research process leads to better targeting, greater sense of ownership, and higher impact (Colfer 2005, Vernooy 2006). Civil society, research, and governmental organizations can offer opportunities for marginalized voices to be heard through multimedia opportunities.

8. Recognize compelling cultural connections to natural resources. Customs, crafts, music, legend, and art reflect place-based, emotional associations. Such profound connections can be more powerful than data in catalyzing change. People's cultural connection to landscapes can support efforts at mediation when working on contentious issues related to natural resource management.

9. Reinvent inventories to include locally valued resources. Traditional forest inventories with a single resource focus such as timber need to give way to other perspectives of forest value, i.e., perspectives of hunters, healers, elderly, youth, and women. A multistakeholder inventory must occur at the outset of resource assessments; otherwise, powerful external interests will control the playing field.

10. Support local champions and intercommunity exchanges. $A$ bond to the land that feeds and shelters one's family can fuel a degree of commitment in communicating information that is unfamiliar in either the academic or conservation community. Donors, researchers, and project managers can identify opportunities to directly support women and other small land holders who are champions. When rural people speak to rural people, the authenticity of the message is ensured through shared experiences born from roots in the farm and forest (Fig. 15).

Responses to this article can be read online at: http://www.ecologyandsociety.org/voll1/iss $2 /$ art28/responses/

\section{Acknowledgments:}

I thank Gloria for her tireless commitment to forest communities. Our research team owes a debt of gratitude to community members of the Capim River who have shared their sobering stories so that other villages may not lose forests. I also thank Aldaberto Veríssimo, Tasso Rezende, Carlos Vicente, Marina Silva, and the scores of Brazilian researchers and policy makers who have shown pioneering efforts in multiple use forestry. Long-term support from Daniel Katz and the Overbrook Foundation was critical in guaranteeing the longitudinal data needed to assess the consequences of logging to livelihoods and in developing novel means for communicating research. People and Plants International, IDRC, and The Christensen Fund have also championed the sharing of local and scientific knowledge. This article benefited from review by Alfredo Fantini, Bruce Campbell, Christopher Barr, and Sheona Shackleton. We commend Ecology and Society for initiating a "Practitioners Award."

\section{LITERATURE CITED}

Agrawal, A., and E. Ostrom. 2006. Political science and conservation biology: a dialog of the deaf. Conservation Biology 20(3):681-682.

Cleary, D. 2006. The questionable effectiveness of science spending by international conservation organizations in the tropics. Conservation Biology 20(3):733-738.

Colfer, C. J. P., editor. 2005. The equitable forest: diversity, community and resource management. RFF/CIFOR, Washington, D.C., USA.

MacDonald, T., director. 2004. Daughters of the canopy [Documentary film]. Canopy Productions, New York, New York, USA. 
Pye-Smith, C. 2003. Fruits of the forest. New Scientist 179(2404, 19 July):36-39.

Saunders, C. D., A. T. Brook, and O. E. Myers Jr. 2006. Using psychology to save biodiversity and human well-being. Conservation Biology 20 (3):702-705.

Shanley, P., and G. Medina, editors. 2005. Frutíferas e plantas úteis na vida Amazônica. CIFOR/Imazon, Belém, Brazil. [online] URL: http ://www.cifor.cgiar.org/publications/pdf files/Books/ BShanley0501.pdf.

Shanley, P., M. Cymerys, and J. Galvão. 1998. Frutíferas da mata na vida Amazônica. Editora Supercores, Belém, Brazil.

Shanley, P., M. Cymerys, and J. Galvão. 2005. Piquiá. Pages 128-130 in P. Shanley and J. Galvão, editors. Frutíferas e plantas úteis na vida Amazônica. CIFOR/Imazon, Belém, Brazil.

Vernooy, R., editor. 2006. Social and gender analysis in natural resource management: learning studies and lessons from Asia. Sage, New Delhi, India. 
Appendix 1. Beneath a tree in the village of Quiandeua, Gloria explains the importance of forest products in the lives of village women. file format: wmv software required to run: Media player 
Appendix 2. Gloria conducts a workshop on the nutritional and healing value of medicinal plants and fruits. file format: wmv software required to run it: Windows Media Player

Please click here to download file 'appendix2.wmv'. 
Appendix 3. Gloria explains the purpose and use of the "Fruit" book. Written to be used by semi-literate rural communities, the illustrated book describes the ecology, use, markets and management of locally valued Amazonian fruit, fiber, oil and timber species. file format: wmv software required to run it: Windows Media Player 